UDC 347.78

DOI https://doi.org/10.31392/NPU-nc.series18.2021.35.07

Synieokyi O. $V$.

\title{
VIRUSES THAT CONTINUE TO KILL ROCK (WHY ARE LEGAL REMEDIES NO LONGER EFFECTIVE?)
}

The article considers current issues related to the legal regulation in the communication system of music recording. The most common ways of violating intellectual property rights in the field of music are described in detail. Characteristic historical examples of infringement of intellectual property rights to musical works and design of music album covers are given. The effectiveness of world practice in the field of copyright protection for musical works is analyzed. There are effective ways to solve the problems of copyright protection on the Internet. There are three types of intellectual property violations in the recording of popular music-plagiarism, counterfeiting and bootlegging. The degree of public danger of everyone is determined. Bootlegging is considered separately as a specific socio-information communications phenomenon. The methodological basis of the study is concrete-historical and descriptive, as well as comparative, dialecticalsystemical, structural-functional analysis. Historical-genetic and terminological methods were used in the analysis of the origin of the concept of bootleg. The legal limits of unofficial releases in the sound recording system are clarified. Thanks to the classification method, a typology of bootlegs is proposed. Characteristic features of bootlegs, similarities and differences with other types of unofficial phonogram production are revealed. The essence of the terms "the official bootleg" and "the unofficial bootleg" is revealed. The information assessment of archive bootleg releases with recordings of rock music is provided. One of the conclusions is that bootlegging is one of the specific types of music piracy, which has its own communication features. The author concludes that the level of music sound flow to be regulated by legal means in the context of global digitalization of information space is ineffective and this trend has an impact on changes in communication formats in the music industry and recording business.

Key words: copyright, bootleg, recording industry, counterfeit, intellectual property, communication space, protection of rights, plagiarism, phonogram.

\section{"We Rock!" \\ Ronnie James Dio}

Perhaps, the best example of a social phenomenon that is very far from "dry" legal science is music. For decades (maybe centuries), two social realities - musical and legal - existed almost in parallel, and it was rather difficult to make them interact successfully. Legal science could not take into account the sensory and emotional perception of musical works as an art category. The musicians, in turn, for obvious reasons were not ready to look at their creations as an "object of law". Nevertheless, for several decades all over the world, the problem of protecting intellectual property objects from unlawful encroachments has been extremely acute. A large number of articles, dissertations, monographs are devoted to this topic. Some researchers are considering the issues of criminal law protection of intellectual property in general. In general, the study of the discourse of intellectual rights is interesting, promising and does not lose its relevance. But if the problem of counterfeit has been investigated quite deeply and very versatile, then the issues of plagiarism by legal scholars and practitioners were touched upon somewhat less. And so far, such an important socio-cultural issue from a legal point of view as the "phenomenon of bootlegging", domestic researchers have so far often bypassed in their fundamental scientific works and academic textbooks. In addition, the musical work was studied as an object of copyright, phonograms were considered as an object of intellectual property rights, and the problems of the implementation of copyright for a musical work in the contractual sphere were also investigated. The regulatory environment for the management of the music industry and related issues in the recording industry is highly specialized. This publication is focused on identifying and analyzing the main types of violations of intellectual rights in the history of musical sound recording, with an emphasis on those aspects that were previously covered in articles, monographs and dissertations insufficiently or not considered at all. That is, we will identify 
and study the viruses that continue to kill rock music. We will also figure out why legal methods are already proving ineffective in the fight against these "viruses".

Rock lives according to its own special laws, customs and specific rules; sometimes this coincides with the established legal norms, and often it does not. Unfortunately, the music industry as a whole (however, like any other socio-economic phenomenon) is inconceivable without violations of certain laws, which means that no one will be surprised that Rock has always received a powerful boost from illegal elements - latent and explicit. Over the years, illegal threads have formed a Parallel Universe, into which plagiarism and counterfeit bootlegging have entered and are steadily operating. Rock music and its recordings need legal protection. Counterfeit phonogram production, contrary to the existing legal prohibitions, has always been and continues to represent a special subject of musical communications. The term "counterfeiting" means a new product created by illegal means, which is similar in most of its visual features to the original carrier. Counterfeiting is a type of unfair competition by misleading the consumer, and the legal nature of this phenomenon is a violation of intellectual rights.

The main criteria for recognizing a musical work as an object of copyright and related rights are originality and an intelligible form. In the absence of evidence to the contrary, the author is considered to be an individual indicated on the original or in a copy of a phono document or on a carrier, cover, packaging, notes, etc. This is the presumption of authorship. Co-authorship can be either inseparable (indivisible) or separate (divisible). With indivisible co-authorship, it is impossible to single out a part of a work created by a specific co-author. In case of separate co-authorship, a clearly designated part of a work created by several persons has one specific author. The combination of music and words leads to the emergence of a new work - a song based, most often, on separate co-authorship.

However, it happens in a different way. In the history of rock music, the creative tandem LennonMcCartney can be considered a classic example of inseparable co-authorship, although in reality John and Paul wrote songs separately. Sometimes such a joint spelling of the authors' surnames is a consequence of the fulfilment of the terms of the contract, but in most cases it is rather a tribute to the traditions that have developed, most often, within the framework of the musical group. For example, since the album "Indelibly Stamped" (1971), SUPERTRAMP Rick Davis and Roger Hodgson have not co-written a single song. The works written by one author are well recognizable and easily distinguishable from the songs of the second. Hodgson is considered one of the most significant composers and lyricists of our time. "Breakfast in America" (1979) was the No 1 worldwide and sold over 20 million copies, making it one of the best-selling albums of all time. After Roger Hodgson left SUPERTRAMP, Rick Davis remained the "owner of the band name". Now, before his next tour, Davis informs Hodgson about this in order to agree on a special restrictive track list with the inclusion of songs that the group in the current line-up is prohibited from performing. In 2005, an attempt to unite the group with Hodgson turned out to be a failure. The musician himself is in excellent shape and with the support of an amazing group in the second half of 2020, he planned to hold "SUPERTRAMP'S ROGER HODGSON: Breakfast in America World Tour 2020" (but the coronavirus prevented).

Plagiarism is as old as humanity. This term has been around for almost 2000 years. Moreover, plagiarism is one of the basic human needs - the same as the punishment for plagiarism. Legally, there are clear guidelines as to where plagiarism begins and where it ends. However, courts sometimes last for years on these issues. In addition, the provisions on the use in compositions of individual fragments belonging to someone else's authorship and previously published have not yet been sufficiently uniformly reflected in the laws. Such can be guitar riffs (several chords), which, unlike melody and text, is not protected by law. Musicians do not hesitate to copy vigorously, which sometimes borders on illegal actions.

Another reason is frivolity, when someone else's idea is used without worrying about the origin. One of the first plagiarism lawsuits against LED ZEPPELIN was filed in 1972 by "Chess Records" in connection with the "Bring It On Home" snippet, borrowed from Sonny Boy Williamson, on "Led Zeppelin II". There are many such controversies: SPIRIT "Taurus" (1968) vs. LED ZEPPELIN "Stairway to Heaven" (1971), THE BIG 3 "The Banjo Song" (1963) vs. SHOCKING BLUE "Venus" (1969), IT'S A BEAUTIFUL DAY “Bombay Calling” (1969) vs. DEEP PURPLE "Child In Time” 
(1970), THE WHO “Young Man Blues” (1970) vs. LED ZEPPELIN “Black Dog” (1971), JETHRO TULL "We Used To Know" (1969) vs. EAGLES "Hotel California" (1976)... [1].

Of all the components of music albums and singles, two objects of greatest interest for misappropriation are the melody and the design of the envelope (or cover). Cover art has truly become an important part of rock music culture. The informative component of the complex of visual perception is integrally embodied through the external design of the carrier in the packaging set of the same name and may contain elements of an artistic (visual) document and/or photo document (cover design), as well as other visual components that perform important functions. In this regard, the third object of illegal use is the visual component - cover design. Album covers are designed using licensed images or borrowed from the public domain from artists of past eras - Denisson's "Fall of Icarus" on the cover of the $1^{\text {st }}$ RENAISSANCE album (1969). During the design of the third album DEEP PURPLE (1969), Bosch's triptych "The Garden of Earthly Delights" - "Musical Hell" was used. The DEEP PURPLE musicians themselves are depicted next to the "Bosch" harp, lute, wheel lyre and drum. The cover of the "Exotic Birds and Fruit" (1974) PROCOL HARUM album contains excerpts from the work of the Hungarian Baroque master Jakob Bogdane. The cover of KANSAS' debut album (1974), adapted from mural by artist John Stuart Curry ... The visual symbol of Swan Song Records - the record labels LED ZEPPELIN and BAD COMPANY - is Icarus, actually copied from William Rimmer's painting "Evening: Fall of the Day". The artist died in 1879 and there are no legal claims. The visual design for "News of the World" (1977) QUEEN is based on a drawing by Frank K. Fries from the science fiction magazine "Astounding Science Fiction" (1953). And no one particularly stutters that this can be qualified as plagiarism. IRON MAIDEN has become recognizable for its music, the fantastic character "Eddie" and the stylish aggressive typeface used since 1980 on the covers of all of the band's albums [3].

However, this was the first time this font was used on the poster of the sci-fi movie "The Man Who Fell to Earth" featuring David Bowie...

The criminal history of music piracy is replete with countless examples - both intricate tricks in the production and distribution of counterfeit phonograms, and theft of discs and tapes with recorded music, committed at the final stage of the production of sound carriers (for example, the story of Dave Glover, which posted on the Internet about 2000 of stolen albums, causing major damage to copyright holders).

The slang term "Bootleg" means an audio or video created and distributed without the permission of the copyright holders. The process of making and distributing such records is known as bootlegging. From the legal point of view, due to the disregard for the legal rules that exist in the music industry, "bootlegging" can be considered a subtype of "audio piracy". From a socio-economic point of view, this phenomenon does not pose a big threat to the music business, since such products are aimed largely at avid collectors and amateur fans. Note that the purchase of bootlegs is not an alternative to the purchase of official publications, but is a kind of exclusive addition to the private collections of music lovers. Without bootlegging, rock music would have lost its unique sector, which, despite its unofficial status, has become an organic part of it over the past half century [2]. Bootlegs most often include "Unreleased", "Unofficial Soundtrack", that is, amateur compilations created on the basis of musical material sounding in a particular film, but which was collected on its own from various third-party sources, with possible additions. A number of bootlegs arose from live performances or from a specially recorded radio session from an FM radio broadcast. Each of these rarities keeps a unique history. Many have recorded "personal compilations" on their tape recorders, randomly choosing the songs they like. With the movement of such homebrew compilations, the audio space was filled with countless quasi-bootlegs. In general, of all possible compilations (legal \& homegrown), ten main types can be distinguished: "Greatest Hits", "Biggest Hits", "The Best of...", "The Singles Collection", "Rarities, Home Tapes \& Out-takes", "Demos Non-Album", "The Lost Tapes", "The Alternate Take", "The B-Sides Collection", "The Unofficial Compilation".

In some cases, the following releases can also be classified as unofficial: 1) Demonstration Releases, that is, trial recordings for preliminary, as a rule, internal demonstration (demo tapes, demos); 2) Promotional Releases; 3) Upcoming Releases, but not yet officially released; 4) Singles Collection and/or B-Sides Collection; 5) Ultra Rarities; 6) All kinds of fan editions (Funbox Edition); 
7) Previously released recordings containing changed material (remakes, remastered versions, tributes, cover versions, remixes, DJ-mixes, backing tracks).

It should be noted that the four extreme positions can also be released officially. A separate place is reserved for such a specific category as "Lost Album". These are full-fledged phonograms that were not released in an official way for various reasons (Unreleased Records). Often, such records appear on the market over time in the status of archived releases. They are sometimes referred to as Lost Tapes. This phrase means "unused" tapes with recordings of individual tracks by a certain artist, known for other releases. And such "Lost Records" are most often (but not in all cases!) ... the same bootlegs, but one more special subspecies. Lost tapes also include "Home Tapes". Separately, attention should be paid to "Deletion" as a technique in the music industry, which can occur for various reasons (for example, when the distribution of a recording is no longer profitable or as a publicity stunt) and at different times (including, even on a day release). Such deleted records are dreamed of by bootleggers.

Musicians can privately record their performances for certain guests, but sound engineers secretly take copies of these recordings and, after processing, put them into circulation. Such bootlegs are sometimes referred to as "Contraband Deck Recordings" or "Soundboard Recording". In some cases, bootlegs appear anonymously as a product released on the market without a brand (record label name), with no elements of corporate identity. But more often than not, manufacturers indicate their name in order to further emphasize the individuality of such a sound carrier with minimal risk of legal sanctions. Since the late 1960s, there have been over 800 bootleg labels in the world. Today the figure is incomparably higher... In the 1970s, many of the bootlegs that came out on LPs were released without covers or an inner insert. There is an aura of freedom in these little-known archival records, and this indicates that they were made at a truly unique time. The demand for all sorts of unofficial live recordings among loyal fans of many rock bands has led to the disappearance of an entire sector of the recording industry into hiding, producing vinyl records based on poorly recorded concert tapes. The poor sound quality of most bootlegs, especially in the 1960s-1980s, is offset by the fact that many of the tracks presented there were not officially released. Most often, in relation to bootlegs, the practice of using the designation Unofficial Recordings has developed, i.e. "Unofficial Records", sometimes "False Releases". But there is a difference between the adjectives "Unofficial" and "Illegal": an unofficial release can in principle be both legal and illegal; an illegal record of official status cannot by definition. If the term "Official Bootleg" in practice means a bootleg released by the musicians themselves or their publishers with a recording of one of their live performances, then the term "Unofficial Bootleg" has no legal meaning at all. Therefore, we propose to exclude this term from circulation, and instead use the "Original Bootleg", by which we mean a released concert (or other) unofficial recording, saved on a medium by the fans themselves or their communities, without the consent of the musicians (the recording of whose performance is contained), or their authorized representatives (producers, managers, agents, lawyers, etc.). The "Official Bootleg" is also "original", but with a higher level of legality. All others are unofficial, unoriginal and other releases, incl. in respect of which there are reasonable suspicions of the illegal origin of the material and its fixation we propose to consider it "Non-Academic Bootlegs". A disc or cassette with bootlegging is not a copy, but an original, often created by the fans of a particular musician without commercial motivation. The management of a number of performers, including those initiated by the latter, is opening special sublabels specializing in the release of "Official Bootlegs" with high-quality recordings of these bands' live performances.

The term "Official (or Legal) Bootleg" means a quality, one might say, unscheduled recording of a performance, created by musicians and/or their publishers. But at the same time such bootlegs should be clearly differentiated from the so-called "Numbered Concert Albums". Such "Live Bootlegs" should be classified as primary documents: most of these releases are original recordings of low quality and often produced in a single copy. Although some bootlegs were included in the TOP of the best live albums. Archived phonograms, revised and updated by inappropriate subjects, circulate in the status of the "Unofficial Remaster Album". A special niche in bootleg space is occupied by acetate records (sometimes they are called "acetate copies of discs" or "acetate copies"), manufactured industrially from hard, brittle plastic or metal with a thin vinyl coating, as well as recordings created 
in Home Studio, including using 8-channel converters (ADAT, DA-80, etc.). Although the quality of broadcasting sound from such acetate discs was higher than usual, their life under standard storage conditions was only about 12 plays. Acetate and promo discs, radio and DJ copies, and other special editions not licensed for broadcast are labeled: Radio Edit, Radio Transmission, For Radio Station Use Only, Audition Copy, D.J. Copy, Sample Copy - Not for Sale, Promotional Copy, Promotional Album, Not Licensed for Public Broadcasting, Not for Resale, Acetate Masters, Acetate Copy...

Radio DJs often invented false names to protect their fresh "discoveries". This practice was introduced in the 1960s by the famous disc jockey Count Suckle [4]. Acetate records containing tracks that were not released on standard releases are of particular collectible interest. For example, only for radio in a limited number, as well as versions of compositions, the performance of which differs from the versions placed on media released in mass circulation. Bootlegs created on the basis of working session recordings (Recording Sessions - Take 1, Take 2...) and received official recognition should be classified as legalized service-musical documents. So, for example, on THE BEATLES "Kum Back", the source material was tape on a reel of Get Back/Let It Be Session, sent to broadcast on WBCN radio station. In September 1969, an acetate record was released with this record, and then as an unofficial release on vinyl. And one more example: The BEATLES "Bootleg Recordings 1963" box set includes a set of four new version of the Heavy \& Coloured Virgin Vinyl and two CDs. This document in the status of Unofficial Release was released in 2014 in a limited edition - only 500 copies. The publisher is "Sapple" (obviously a revised name for the original "Apple").

DJs often ordered acetate copies of their most valuable recordings. As a result, the race for rarities created fertile ground for counterfeits, pirated copies and records with fictitious names. Famous in the 1980s, the slogan "Home Taping is Killing Music and It's Illegal" was prompted by the rise in popularity of cassette recorders and fears that private recordings of music radio programs on cassettes could lead to reduced sales of phonograph records. The BPI logo included a cassette silhouette image. Digging deep into the niche of unofficial recordings and compiling bootlegographs of favourite bands is a fascinating exploration challenge for avid rock amateurs, and the findings are helping to study the history of rock in sound recording. So, counterfeit music products can be classified into illegal copies of officially released media and the so-called "ostensibly originals", the legal counterparts of which do not exist in nature. As criteria for defectiveness, two main features are distinguished: in form and in content.

The mechanism of shadow and "grey" communications in relation to sound recording as a system of a higher level acts as a triune virus that almost killed rock: 1) counterfeit products manufactured in mass circulation for wide distribution (high level); 2) bootlegging as a means of artisanal replication and distribution of unofficial recordings among a relatively narrow circle of amateurs (intermediate level); 3) rewriting music at home for personal use (low level).

So, for today it looks like legal vaccination is canceled? And now the coronavirus pandemic has finally finished off the music business - concerts, tours, live rock shows have been canceled, studio recordings are being made remotely, record stores are closed. Sorry, our favourite Rock, "Come on, Goodbye”!

Or is there still a chance to survive? No one can know for sure...

In general, the study of the discourse of intellectual rights is interesting, promising and does not lose its relevance in the recording industry.

\section{Bibliography:}

1. Bergert M. Plagiate: Gestern und Heute. Eclipsed Journal. 2020. No. 221. Pp. 56-61.

2. Marshall L. Bootlegging: Romanticism and Copyright in the Music Industry. SAGE Publications Ltd. 2005. $192 \mathrm{p}$.

3. Sulzbacher T. "Eddy the Ead". Rock Classic: Iron Maiden. Das Sounderheft. 2020. No. 23. Pp. 35-37.

4. Synieokyi O.V. "John Peel Sessions" (Informational Review of the "BBC Radio 1" Archival Sound Records 1960s-1970s). Scientific and pedagogic internship "Innovative Methods of the Organisation of the education process in Ukraine and EU Countries”. 2021. Pp. 55-60. 


\section{References:}

1. Bergert, M. (2020). Plagiate: Gestern und Heute. Eclipsed Journal. 221. Pp. 56-61.

2. Marshall, L. (2005). Bootlegging: Romanticism and Copyright in the Music Industry. SAGE Publications Ltd. 192 p.

3. Sulzbacher T. (2020). "Eddy the Ead". Rock Classic: Iron Maiden. Das Sounderheft. 23. Pp. 35-37.

4. Synieokyi, O.V. (2021). "John Peel Sessions" (Informational Review of the "BBC Radio 1" Archival Sound Records 1960s-1970s). Scientific and pedagogic internship "Innovative Methods of the Organisation of the education process in Ukraine and EU Countries". Pp. 55-60.

\section{Синсокий О. В. Віруси, що продовжують вбивати рок (чому правові способи захисту} вже не с ефективними?)

У статті розглянуто актуальні проблеми, щзо пов'язані з правовим регулюванням у комунікаційній системі музичного звукозапису. Докладно описано найбільш поширені способи порушення інтелектуальних прав у музичній сфері. Наведено характерні історичні приклади порушення права інтелектуальної власності на музичні твори та оформлення обкладинки музичних фонодокументів. Проаналізовано ефективність світової практики у сфері захисту авторських прав на музичні твори. Зазначено ефективні шляхи вирішення проблем охорони об'єктів авторських прав у мережі Інтернет. Виділено три види порушень інтелектуальних прав у звукозапису популярної музики - плагіат, контрафакт та бутлегерство. Визначено ступень суспільної небезпеки кожного. Окремо розглядається бутлегерство як специфічне соиіально-інформаційне комунікативне явище. Методологічною основою дослідження є конкретно-історичний та описовий методи, а також порівняльний, діалектико-системний, структурно-функиіональний аналіз. Під час аналізу походження поняття «бутлег» застосовувався історико-генетичний і термінологічний методи. 3'ясовано правові межі неофіиійних випусків у системі комунікацій звукозапису. Завдяки класифікаційному методу запропоновано типологію бутлегів. Виявлено характерні ознаки бутлегів, визначено подібності та виявлено відмінності від інших типів неофіційної фонограмної продукиії. Розкрито сутність термінів «офіиійний бутлег» $i$ «неофіиійний бутлег». Надається інформаџійна оиінка архівних бутлег-релізів із записами рокмузики. Один з висновків полягає у тому, щчо «бутлегерство» є одним зі специфічних видів «музичного піратства», якому властиві специфічні комунікачійні особливості. Автор доходить висновку, що рівень музичного аудіопотоку вже неефективно регулювати за допомогою виключно правових засобів в умовах глобальної цифровізації інформаційного простору, і ией тренд накладає відбиток на зміни форматів комунікації в музичній індустрії та звукозаписувальному бізнесі.

Ключові слова: авторське право, бутлег, індустрія звукозапису, контрафакт, об'єкти інтелектуальної власності, комунікаційний простір, захист прав, плагіат, фонограма. 